Pobrane z czasopisma Studia Bia?orutenistyczne http://bialorutenistyka.umcs.pl Data: 26/04/2023 11:21:23

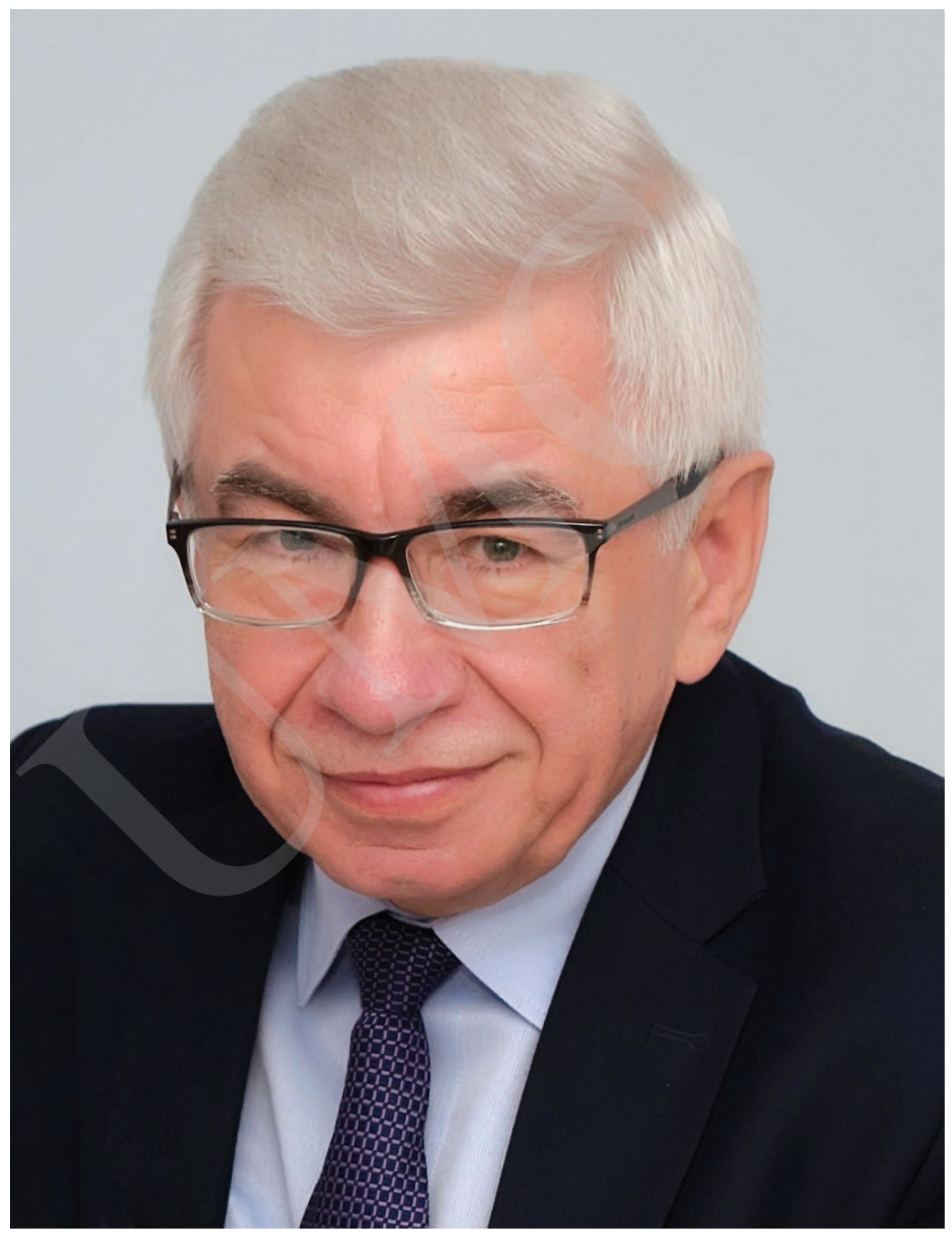

Numer jubileuszowy dedykowany

Profesorowi Michałowi Sajewiczowi w 70. rocznice urodzin 


\section{Prof. dr hab. Michał Sajewicz - a researcher into the Polish-East Slavonic borderland, a populariser of research on Belarus and Belarusians, and a teacher. Laudatio in Honour of Professor Sajewicz}

It is my great honour and pleasure to give a laudatio for the Honourable Professor Michał Sajewicz - a person of not only extraordinary academic merit, especially in the field of Slavonic Studies and Belarusian Studies, but also of immense importance to me, personally. For it is without exaggerated courtesy but with deep conviction that I - and forgive this personal note - believe in the great impact Professor Sajewicz had on me already as the Supervisor for my Master's thesis, informing my decisions and, eventually, guiding my professional career. Now, after more than 20 years of my acquaintance with you, Professor, on this beautiful and grand occasion, I would like to express my sincere gratitude to you for your generous and understanding support in finding my way, for showing me the research tools and pointing my inquiries in the right directions, for providing me with all the inspiring works by the greatest Polish and European Slavicists, and, finally - for the open-mindedness, understanding and patience I have oft experienced from you, Professor.

It is my honour to present to you a brief biography of our Distinguished Guest, including some of the materials from his family archive. Professor Michał Sajewicz was born on 15 June 1949 in Lewkowo Nowe, located at the edge of the picturesque Białowieża Forest. He spent his childhood and early teenage years there. Between 1956 and 1963 he attended primary school in the nearby Lewkowo Stare, from which he graduated with honours. In 1963 he continued his education at the General Secondary School No. 10 in Hajnówka, an establishment which provided additional tuition in the Belarusian language. During his time there he developed a passion for Polish and foreign literature, and for the folklore of the eastern parts of the Białystok region. His philological interests had led him to study Russian Philology at the Maria Curie-Skłodowska University (UMCS) in Lublin. In 1967 he enrolled with the University as a first-year student of Russian Philology.

Our Distinguished Guest was interested in linguistics already as a student. During his first year he joined the Linguistics Group of the Russian Philologists Research Club. He distinguished himself as a passionate and creative researcher, hard-working, conscientious and uniquely committed in everything he did in the academic commu- 
nity. These attributes, as well as the general sympathy he enjoyed from the faculty and the student community, had led to his election as Club Chair for the academic year 1968-1969. In this capacity the prospective graduate of Russian Philology could present numerous papers at international and Polish conferences for students (and not only), at which he garnered multiple awards: Lublin (1969) - third place (equal with Halina Rycyk), Warsaw (1970) - first place (equal with Halina Rycyk), Pécs, Hungary (1970) (equal with Halina Rycyk) - first place, Gdańsk (1971) - honourable mention, Krakow (1972) - first place. The paper he presented at the 1969 Lublin conference was published in 1971 in Tartu, Estonia.

In 1971 Michał Sajewicz organised a student research camp in Narewka (the Hajnówka poviat of the Białystok Voivodeship) for members of the UMCS Russian Philologists Research Club. As a third-year student, he participated in field dialectological studies (conducting surveys in the villages of Lewkowo Stare and Lewkowo Nowe). In 1970 he took his Master's seminar (with a linguistics focus) under prof. dr hab. Michał Łesiów. Soon after he decided that the title of his Master's thesis would be: Gwara ruska okolic Narewki w powiecie hajnowskim (fonetyka-fleksja) ${ }^{1}$. Highly praised by the reviewers, this work was the first comprehensive description of the phonetics and inflection of the Belarusian dialects of the Narewka area in the Białystok region. In 1972 the thesis earned Michał Sajewicz the professional title of Master of Russian Philology, significantly shaping the future of the young graduate. On 01 October $1972 \mathrm{mgr}$ (MA) Michał Sajewicz obtained employment at the Institute of Russian and Slavonic Philology of the UMCS in Lublin.

As a young research-and-teaching assistant, Michał Sajewicz continued his research on noun formation in the Belarusian dialects of the Narewka area. Within two years (1974-75) he has compiled an extensive body of about 5,000 deverbal, deadjectival and desubstantive noun derivatives with the affix as a transpositional, modifying and mutative function. (It is worth adding that this lexical corpus would be later extended to include, as at 1986, more than 10,000 derivatives).

Sajewicz's interest in Slavonic studies and his relentless drive to expand knowledge and discover new research perspectives and approaches, coupled with his commitment and passion, garnered him recognition from his immediate superiors. In 1975 mgr Michał Sajewicz took a three-month fellowship at the Institute of Slavonic Studies of the Polish Academy of Sciences in Warsaw, and in 1978 he took a three-month fellowship at the Taras Shevchenko National University of Kiev. After returning from Kiev Sajewicz undertook research on the agricultural vocabulary of Eastern Slavonic dialects in the Białystok region. The research yielded lexical material from the Belarusian dialects of the Lewkowo Stare area and the Ukrainian dialects of the Dubicze Cerkiewne area. His (and Professor F. Czyżewski's) findings were published in

\footnotetext{
The Belarusian dialect of the Narewka area in the Hajnówka poviat (phonetics - inflection).
} 
1979 under the title Zróżnicowanie słownictwa rolniczego w kilku gwarach wschodniosłowiańskich na polsko-białorusko-ukraińskim pograniczu językowym².

In 1983 Michat Sajewicz earned the degree of Doctor of Humanities based on his 624-page doctoral dissertation entitled: Stowotwórstwo rzeczowników w gwarach wschodniostowiańskich na terenie bytego powiatu hajnowskiego ${ }^{3}$ (supervised by prof. dr hab. Marian Jurkowski [University of Warsaw] and prof. dr hab. Stefan Warchoł [UMCS]). In the following years dr Michał Sajewicz continued his research on noun formation in the Belarusian dialects of the Białystok region. Initially, he conducted his explorations in the gminas of Narewka and Białowieża, and later also in a number of villages on the Narew River (30 locations). This extensive period of research yielded a large body of 3,485 deverbal, deadjectival and desubstantive names of subjects with a suffix, as well as more than a dozen research papers on noun formation in the Belarusian dialects of the Białystok region, including Dublety strukturalne w kategorii dewerbalnych nomina agentis $w$ gwarach z pogranicza białorusko-ukraińskiego na Białostocczyźnie (1989); Produktywne typy stowotwórcze dewerbalnych nazw agentywnych w gwarach białoruskich okolic Narewki i Białowieży na Białostocczyźnie (1990); Dewerbalne nomina agentis z formantami '-to', '-un' $w$ gwarach białoruskich okolic Narewki na Białostocczyźnie ${ }^{6}$ (1995); Suffiksalnoje stowoobrazowanije otgłagolnych nazwanij subjektow diejstwij $w$ biełorusskich goworach wierchniego tieczenija rieki Nariew w bietostokskom riegionie ${ }^{7}$ (2000); Desubstantywne osobowe nazwy subiektów właściwości z formantem sufiksalnym w nadnarwiańskich gwarach biatoruskich Białostocczyzny ${ }^{8}$ (2000); Dewerbalne osobowe 'nomina subiecti' z formantem sufiksalnym w nadnarwiańskich gwarach białoruskich Białostocczyzny ${ }^{9}$ (2001); O jednym przykładzie oddziaływania polskiego języka literackiego na system stowotwórczy gwar biatoruskich Białostocczyzny ${ }^{10}$ (2001); Z metodologii badań nad

2 The diversity of agricultural language in several Eastern Slavonic dialects at the Polish-Belarusian-Ukrainian linguistic frontier.

3 Noun formation in Eastern Slavonic dialects of the former Hajnówka poviat.

4 Structural doublets in the category of deverbial 'nomina agentis' in Belarusian-Ukrainian borderland dialects in the Białystok region.

5 Productive types of word formation in deverbal agentive nouns from the Belarusian dialects of the Narewka and Białowieża area in the Białystok region.

6 Deverbal nomina agentis with '-ło' and '-un' affixes in the Belarusian dialects of the Narewka area in the Białystok region.

7 Suffix word formation of the verbal names of the subjects of actions in the Belarusian dialects of the upper reaches of the Narew river in the Bialystok region.

8 Desubstantive personal names of proper nouns with suffixes in the Narew River area dialects of the Bialystok region.

9 Deverbal personal nomina subiecti with suffixes in the Narew River area dialects of the Białystok region.

10 The influence of Polish literary language on the word formation system of the Belarusian dialects of the Białystok region - an example. 
słowotwórstwem peryferyjnych gwar biatoruskich Biatostocczyzny ${ }^{11}$ (2001); Badania nad stowiańskim stowotwórstwem gwarowym (kilka postulatów metodologicznych) ${ }^{12}$ (2003).

In parallel to his field studies into dialects, dr Michał Sajewicz was working on his habilitation dissertation on the names of subjects in the Belarusian dialects of the Narew River areas in the Białystok region. In 2002 these efforts culminated in the publication of a monograph entitled Derywacja sufiksalna osobowych nazw subiektów w nadnarwiańskich gwarach bialoruskich Białostocczyzny. Deverbativa, deadiecti$v a^{13}$. In January $2003 \mathrm{dr}$ Sajewicz submitted his monograph to the Council of the Faculty of the Humanities at the UMCS as a habilitation dissertation. In this publication he discussed the derivation of personal subject names in the Belarusian dialects of the Narew River areas in the Białystok, comparing them to other dialects. These included primarily Belarusian, partly Ukrainian and, to a lesser extent, Polish dialects. He also offered comparative perspectives on the Belarusian, Ukrainian and Polish literary language. In his monograph Sajewicz also dealt fairly extensively with the selected aspects of the theory of synchronic word formation (including the notion of the synchronic derivative - proper and associative derivatives, and bilaterally and unilaterally analysable derivatives), motivation as the primary morphological relation, the types and directions of motivation, word-formation analysis and morphemic analysis (the notions of morpheme and submorpheme), the affix and its types, the evolution of the notion of affix (morphemic and non-morphemic elements as a function of affixes), derivation types, the semantic structure of derivatives, the notions of derivational type and derivational category, the number and activity of derivational types. Drawing on a large body of material (2,630 derivatives), the monograph gained acclaim from the reviewers: prof. dr hab. Elżbieta Smułkowa, prof. dr hab. Michał Kondratiuk and prof. dr hab. Stanisław Grabias. The habilitation examination took place on 25 June 2003.

After obtaining the degree of Habilitated Doctor in Slavonic Linguistics, Michał Sajewicz focused his research on the following subjects:

- the formation of nouns in the Eastern Slavonic dialects of the Białystok region, with a particular focus on the Belarusian dialects of the Narew River area;

- the anthroponymy of the Polish-Belarusian-Ukrainian linguistic frontier (central and southern parts of the Białystok region);

- the ethnic, religious and linguistic diversity of the inhabitants of the eastern parts of the Białystok region;

- Belarus - a country between East and West; the past and the present.

11 On the methodology of research into word formation in the peripheral Belarusian dialects of the Białystok region.

12 Research on word formation in Slavic dialects - a number of methodological postulates.

13 The suffixal derivation of personal subject names in the Belarusian dialects of the Narew River areas in the Białystok region. Deverbals, deadjectivals. 
Following his habilitation prof. dr hab. Sajewicz devoted much of his research attention to the anthroponymy of the Polish-Belarusian-Ukrainian linguistic frontier, focusing primarily on the anthroponymy found in the Hajnówka poviat in the Białystok region. Some of his most notable papers deal with such subjects as the different names for wives in the Narew River Belarusian dialects of the Białystok region - see Slowotwórstwo nazw żon w nadnarwiańskich gwarach białoruskich Białostocczyzny ${ }^{14}$ (1998); Nazwy żon z formantami '-i $\chi a$ ', '-ča' w gwarach białoruskich okolic Lewkowa Starego na Białostocczyźnie ${ }^{15}$ (2000), Zmiany w żeńskim imiennictwie osobowym prawostawnych mieszkańców powiatu hajnowskiego na Biatostocczyźnie jako rezultat asymilacji kulturowej ${ }^{16}$ (2006); Zmiany w imiennictwie osobowym prawostawnych społeczności powiatu hajnowskiego na Białostocczyźnie ${ }^{17}$ (2007) - and the nicknames given to the inhabitants of selected locations on the Belarusian-Ukrainian linguistic frontier in the Białystok region (see Przezwiska mieszkańców kilku wsi z białorusko-ukraińskiego pogranicza językowego na Białostocczyźnie ${ }^{18}$ (1999), Zmiany w męskim imiennictwie osobowym prawosławnych mieszkańców powiatu hajnowskiego na Białostocczyźnie jako rezultat asymilacji kulturowej ${ }^{19}$ (2010); Nowe trendy w męskim nazewnictwie osobowym $w$ prawosławnych społecznościach powiatu hajnowskiego na Białostocczyźnie ${ }^{20}$ (2007); Najnowsze trendy w imiennictwie osobowym prawostawnych społeczności powiatu hajnowskiego na Białostocczyźnie ${ }^{21}$ (2012). Also, he explored the subject of zoonyms found in the dialects of the Polish-Belarusian-Ukrainian borderland in the Białystok region - see Ze studiów nad zoonimia polsko-białorusko-ukraińskiego pogranicza językowego na Biatostocczyźnie 22 (1996). Moreover, prof. dr hab. Sajewicz made invaluable contributions to several multi-author atlases of dialects: Atlas gwar wschodniostowiańskich Pobuża (in cooperation with prof. F. Czyżewski), Atlas etnolingwistyczny Pobuża, Atlas gwar Polskich (written at the University of Lodz under the supervision of prof. dr hab. K. Dejna).

14 Word formation in wive's names in the Belarusian dialects of the Narew River area in the Białystok region.

15 Wive's names with '-ixa', ' $-\check{c} a$ ' affixes in the Belarusian dialects of the Lewkowo Stare area in the Białystok region.

16 Changes in the feminine personal-naming system of the members of the Orthodox Church living in the Hajnówka poviat of the Białystok region due to cultural assimilation.

17 Changes in the personal naming system of the Orthodox Church communities living in the Hajnówka poviat in the Białystok region.

18 Nicknames of the inhabitants of several Belarusian-Ukrainian borderland villages in the Białystok region.

19 Changes in the masculine personal-naming system of the Orthodox Church members living in the Hajnówka poviat of the Białystok region due to cultural assimilation.

20 New trends in the masculine personal-naming system of the Orthodox Church communities living in the Hajnówka poviat of the Białystok region.

21 Latest trends in the personal-naming system of the Orthodox Church communities living in the Hajnówka poviat of the Białystok region.

22 Studies on zoonyms in the Polish-Belarusian-Ukrainian linguistic frontier of the Białystok region. 
The 725-page monograph entitled Nazwiska patronimiczne z formantem '-uk' w powiecie hajnowskim na Białostocczyźnie na tle ogólnopolskim ${ }^{23}$ (2013) crowned Sajewicz's long, meticulous and dedicated research. The multifacetedness of the monograph stemmed from the wide-ranging studies Professor Sajewicz conducted in the 1990s to explore the ethnic, religious and linguistic diversity of the eastern parts of the Białystok region. Innovative in many respects, this work was preceded by a number of research papers, including Zróżnicowanie etniczno-językowe wiejskiej społeczności prawosławnej Białostocczyzny w świetle badań naukowych oraz w oczach mieszkańców tego regionu ${ }^{24}$ (2003); Zagadnienie przynależności etniczno-językowej prawosławnych mieszkańców powiatu hajnowskiego na Biatostocczyźnie ${ }^{25}$ (2008); Nasza $i$ wasza mowa. Zagadnienie przynależności etniczno-językowej prawosławnych mieszkańców powiatu hajnowskiego w województwie podlaskim ${ }^{26}$ (2010). A product of indepth analyses spanning the fields of linguistics and social studies, the papers allowed their author to look at the Białystok region, his 'little homeland', not only through the eyes of a philologist, dialectologist and onomast, but also from the perspective of a member of the local community, aware of his strong ties with the region's history.

The 2013 monograph was a pioneering work. Michał Sajewicz was the first Polish linguist to have demonstrated that the name affix '-uk' was, at the time, the most active in the south-eastern parts of the Białystok region, an area historically populated by Ruthenians coming from the south - from the Bug River and Polesia regions.

The community of Slavonic philologists considered the monograph a model piece of research, not only meeting, but also going way beyond all the criteria imposed by the government on these types of publications. Sajewicz's work garnered acclaim on both sides of the border, and the reviewers highlighted the author's great contribution to the Slavonic anthroponymy, the solid theoretical foundations, and the detailed and in-depth analysis based on a large body of source materials, as well as the extensive use of literature on the subject. Last but not least, or perhaps most importantly, they praised the author's considerable knowledge and research experience. In the words of prof. dr hab. Sławomir Gala (University of Lodz):

Michał Sajewicz's work (...) is indisputably a seminal piece on Polish and Slavonic onomastics and anthroponymy. Notably, the monograph offers a perspective on the titular type of names that is limited to a poviat, but also one that is set against the broad Polish and Eastern Slavonic context. What is also commendable is Sajewicz's research approach, which amal-

${ }^{23}$ Patronymic names with the -uk affix in the Hajnówka poviat of the Białystok region as compared to the rest of Poland.

24 The ethno-linguistic diversity of a rural Orthodox Church community in the Białystok region in the light of existing research and as viewed by the region's inhabitants.

25 The issue of ethno-linguistic affiliation among Orthodox Church members living in the Hajnówka poviat of the Białystok region.

26 Your tongue and our dialect. The issue of ethno-linguistic affiliation among Orthodox Church members living in the Hajnówka poviat of the Podlaskie Voivodeship. 
gamates the attributes of a linguistic - i.e. onomastic - perspective with cultural facts, the latter being a highly relevant factor in anthroponymic studies.' (from the publisher's review).

\section{Prof. dr hab. Leszek Bednarczuk stressed that}

this monumental monograph constitutes the most extensive study of Eastern Slavonic anthroponyms I have ever seen, and the methodology makes it one of the greatest pieces of onomastic synthesis ever written in the Polish language. What strikes you most is the considerable effort expended by the author in amassing and meticulously analysing the large body of material.

Prof. Irina Gaponienko from the Belarusian State University made the following remarks on the monograph:

У цэлым навуковая праца М. Саевіча з'яўляецца ўзорнай для даследчыкаў славянскай антрапаніміі пры вывучэнні канкрэтных прозвішчных разнавіднасцей. 3 распрацовак падобнага тыпу ў перспектыве можа скласціся цэласная карціна станаўлення славянскай антрапанімічнай сістэмы ${ }^{27}$.

These reviews, as well as Professor's biography and research achievements, make a strong case that his upcoming monograph entitled Odczasownikowe pejoratywne nazwy subiektów z formantem sufiksalnym $w$ gwarach białoruskich okolic Lewkowa Starego na Białostocczyźnie ${ }^{28}$ Lublin: Wydawnictwo UMCS, 2019, 349 pages - will prove an equally seminal work on agentive-name formation in that region.

The discussion of Michał Sajewicz's work would not be complete without mentioning his ethno- and sociolinguistic research devoted to such subjects as: 'little homelands' in Eastern Orthodox rural communities of the Białystok region Wyobrażenie ,matej ojczyzny" w białoruskojęzycznych wspólnotach wiejskich na Białostocczyźnie ${ }^{29}$ (1993); Ujaulennie małoj radzimy u biełaruskamounych wiaskowych supolnasciach na Biełas-

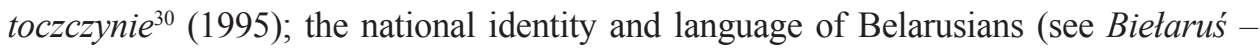
niezależnaja, demakratycznaja dziarżawa ci zabyty swietam etnahraficzny kutok? ${ }^{31}$

${ }^{27}$ In general, the scientific work of M. Sajewicz is exemplary for the researchers of Slavic anthroponymy in the study of specific nominal varieties. From the works of this type, it is possible to form a holistic picture of the formation of Slavic anthroponymic system in perspective'. Рэцэнзія: Michał Sajewicz. Nazwiska patronimiczne z formantem -uk w powiecie hajnowskim na Białostocczyźnie na tle ogólnopolskim, Lublin, 2013. 725 pages, Веснік БДУ. Серыя 4, Філалогія. Журналістыка. Педагогіка. 2015. № 1. pp. 91-92.

28 Deverbal pejorative subject names with suffixes in the Belarusian dialects of the Lewkowo Stare area in the Białystok region.

29 The notion of 'little homeland' in the Belarusian-language rural communities of the Białystok region.

30 The concept of small motherland in Belarusian rural communities in the Bialystok region.

31 Belarus - is it an independent democratic state or an ethnographic corner forgotten by the world? 
(2000)), folk stereotypes (see Ludowy stereotyp burzy (na wspótczesnym materiale ze wschodniej Polski) ${ }^{32}$ (1994), folk rituals (see Obrzęd Kupaty na Biatorusi ${ }^{33}$ : 1999)). Furthermore, he published a range of papers on Belarus and its people, past and present, see Białoruś - Kraj między Wschodem i Zachodem ${ }^{34}$ (2006); Kraj między Wschodem $i$ Zachodem ${ }^{35}$ (2010); Uwarunkowania kulturowo-socjologiczne pogranicza wschodniego (wybrane aspekty zagadnienia ${ }^{36}$ (2006). In his works at the intersection of ethnography, social science and linguistics, Professor Michał Sajewicz demonstrated his typically thorough approach to analysing the titular subjects. These publications shared a common denominator - a respect for the otherness and multiculturalism of the area in question, as well as for another person, who should be able to fully enjoy their civil rights whatever their religion, ethnicity and beliefs. So little and yet so much.

It should be added that Professor Sajewicz knows Belarus inside out, understanding this country and its people like few others do. It is, then, not by coincidence that in one of his papers in the field of folklore and ethnolinguistics he explored the joyful Kupala Night, a festivity which brings together all members of the local community regardless of their ethnicity, religion and financial status. Professor takes a ceremonious approach to each of his visits to Belarus or his native parts in the Białystok region. He feels a special sympathy for the people of both Poland and Belarus, and he has manifested this on many occasions, both during formal events (symposia and conferences) and in less formal discussions on what the two nations have in common.

Michał Sajewicz's long fascination with Belarus and the Polish-Belarusian-Ukrainian cultural and linguistic frontier is reflected in his extensive body of works, only a small portion of which I have discussed here, numbering a total of more than 160 publications, including 3 monographs, more than 80 research papers, 24 book reviews and endorsements, 11 edited multi-author publications, as well as a range of popular scientific texts, translations from Eastern Slavonic languages into Polish, special-occasion speeches, biographies and biographical notes.

It is also important to note that Professor Sajewicz led the establishment of Belarusian Studies in Lublin. It is partly due to his efforts that the UMCS in Lublin established a programme in Belarusian Philology. Originally established as the Belarusian Language and Literature Laboratory, now the Institute of Belarusian Studies operates within the Institute of Belarusian and Bulgarian Studies. This year marks its $25^{\text {th }}$ anniversary. As the long-standing Head of the Institute (and continuing in this position), prof. dr hab. Michał Sajewicz has been making his best endeavours to help it flourish and play an important role in the academic life of not only our University, but also in the Belarussian Studies community. Suffice it to say that between 1993 and

\footnotetext{
Storm-related folk stereotypes based on modern-day material from eastern Poland.

33 Kupala Night Rituals in Belarus.

34 Belarus - a country between the East and the West.

35 A country between the East and the West.

36 The cultural and sociological background of the Eastern borderland - selected aspects.
} 
2018 the faculty members of the UMCS's Institute of Belarusian Studies published 40 monographs, and more than 650 research papers and popular scientific articles, reviews, conference reports, book endorsements, special-occasion publications and translations. In the last four years alone they presented 47 papers at international and Polish research conferences organised in Poland and beyond. It is on Professor Sajewicz's initiative in 2007 - when no one expected that a journal paper would be valued more than a monograph chapter, and when no one measured academic achievements in points - that, in cooperation with prof. dr hab. Ryszard Radzik, the Studia Biatorutenistyczne (Belarusian Studies) was founded, becoming a showcase and a hallmark of Lublin's Belarusian Studies. Using his extensive contacts, prof. dr hab. Sajewicz had the most prominent scholars in the field - from Poland and abroad - write papers already for the first issue. These included Aleksander Barszczewski, Mikoła Chaustowicz, Arnold McMillin, Sergei Zaprudsky, Aleksandr Smalanchuk, Gennadyi Sahanovich and Sergei Tokc. Between 2007 and 2018 the yearbook featured a total of 215 research papers, more than 90 book reviews and endorsements, 25 conference reports and two biographic articles.

What has also helped the journal develop was Professor's unique commitment to the academic life. After habilitation he participated in 30 research conferences -10 abroad (Minsk, Brest, Vitebsk and Bryansk) and 20 in Poland (Lublin, Kraków, Warsaw, Białystok, Biała Podlaska, Zamość, Suwałki, Hajnówka, Rossosz, Wisznice). At these conferences he presented papers on word formation in dialects, with a particular focus on noun formation in the dialects of the Polish-Belarusian-Ukrainian linguistic frontier, the anthroponyms of the eastern parts of the Białystok region, and the socioand ethnolinguistics of the Polish-Belarusian-Ukrainian frontier. Moreover, Professor Sajewicz has co-organised 15 international research conferences at the University of Warsaw, the Belarusian State University in Minsk and the Brest State AS Pushkin University. He has also been a five-time Chair of the Organisational Committee of all the editions of a series of conferences entitled 'The Polish-Belarusian cultural, literary and linguistic ties' (Kraków 2004, Lublin 2008, 2010, 2012; Wisznice 2017).

Teaching has been an equally important part of Professor's work. In addition to countless hours of instruction provided to students of Slavonic Studies, Russian Philology and Russian Studies at several universities, including the UMCS in Lublin, the John Paul II Catholic University of Lublin (1989-2009), The State School of Higher Education (PWSZ, 2006-2013), Professor Sajewicz has supervised more than 450 Master's and Bachelor's theses of Russian Philology, Belarusian Philology and Ukrainian Philology students. Furthermore, he provided two scholars (I had the honour to be one of them) with guidance in preparing and defending doctoral dissertations in the field of Slavonic linguistics. He has reviewed doctoral dissertations and (two) habilitation dissertations, and provided his opinion in a professorial procedure. Professor has also reviewed many Master's theses supervised by other members of faculty at UMCS's Institute of Slavonic Philology. 
As a supervisor of theses and dissertations, Professor Sajewicz has admittedly enjoyed great respect among students, and the fact that many of them chose to have him as their supervisor was not only due to his being known in the student community as a highly knowledgeable and competent expert, but also owing to his dedication to the supervisees, taking time and effort to provide them with the theoretical and methodological preparation they would need to investigate the subjects of their choice. He has always made sure that the theses and dissertations are of high quality, and encouraged their authors to ensure they are well-documented and written independently. Aware of Professor Sajewicz's vast knowledge and the fact that he can speak several Slavonic languages and read research literature in all of them, they have never risked copying whole passages from published sources. And this at a time when no one knew that the anti-plagiarism software would one day come into use.

Professor Sajewicz can, like no other person, enjoy the successes of his tutees, motivate them to work hard on constructive critiques, and inspire them to look for original and creative approaches. Despite being an excellent mentor and guide, he does not try to impose his points of view at all cost. Quite on the contrary, he appreciates independent thinking, creativity, the autonomous pursuit of truth and steadfast views. In his research work he has championed accuracy, thoroughness, attention to detail and multifacetedness, as well as the ability to present diverse perspectives and use various research tools. Nothing is, and should be, black and white at Professor's seminars. The task of any researcher, including one who has only just started their scholarly pursuits, is to discover the middle ground, to see what is, paradoxically, the most difficult to notice. The theses and dissertations supervised by Professor Sajewicz has earned many awards from the UMCS's Rector, and he has also received multiple congratulation letters in recognition of his contributions.

He has also made notable contributions to the UMCS's Faculty of the Humanities, including especially the Institute of the Slavonic Philology, at which he served in multiple managerial roles, including as Deputy Head of the Russian Language Institute at the UMCS Institute of Slavonic Philology (1992-1993), Head of the Belarusian Language and Literature Laboratory at the UMCS's Institute of Slavonic Philology (1997-2005), Head of the Institute of Belarusian Studies (2005-2018) and Head of the Institute of Belarusian and Bulgarian Studies (2018-2019). He served two terms (2003-2009) in the capacity of Deputy Head of the UMCS Institute of Slavonic Philology, and from 01 September 2013 to the end of August 2018 he was Head of the Institute. Moreover, he chaired the Institutes's Research Committee and Development Strategy Committee, and was a member of the Development Strategy Committee of the Faculty of the Humanities. Between 2006 and 2013 Professor M. Sajewicz was a member of the Senate of the State School of Higher Education in Zamość (PWSZ). Since 1983 he has been regularly appointed to doctoral committees to conduct examinations in the Russian language. To date he has examined more than 150 members of research-and-teaching and research-and-technical staff and librarians from the UMCS and other universities. 
Furthermore, Professor Sajewicz is a member of the Minsk-based Association of Belarusian Studies Scholars, and of many Polish research societies. Between 2004 and 2018 he was Chair of the Central Board of the Polish Society of Belarusian Studies Scholars, and he continues to be a member of the Lublin Research Society and the Ethnolinguistics Committee of the Linguistics Committee at the Polish Academy of Sciences. Between 2007 and 2018 Professor Sajewicz served as Chair of the Editorial Board of the Studia Biatorutenistyczne yearbook, and since 2010 he has been a member of the International Publishing Board of the Vestnik BSU journal published by the Belarusian State University in Minsk. Furthermore, he is a member of the Editorial Board of the Acta Albaruthenica yearbook (Warsaw), the Advisory Council of Facta Simonidis (PWSZ in Zamość), and a former member of the Editorial Board of Rozprawy Slawistyczne (1994-2008). Also, he was a member of the Editorial Board of the Lublin-published Etnolingwistyka journal.

In recognition of his merits as a researcher, teacher and organiser, Professor Sajewicz has been conferred the Gold Cross of Merit, the Gold Medal for Long Service and the Medal of the Commission of National Education, and also he received several UMCS Rector Awards (including second-degree awards).

In ending, I would like to quote Leszek Bednarczuk's words. When discussing our Distinguished Guest's work, he stated that 'his papers and other numerous linguistic works published in Poland and abroad put Professor Sajewicz among the greatest scholars in the field of Belarusian Studies'.

Dear Professor, I would like to wish you, personally and on behalf of the UMCS Institute of Slavonic Philology staff and all the Guests and Participants gathered here for the Conference, the best of health, cheerfulness and satisfaction from everything you do, and a lot more successes in both your private and professional life! Ad multos annos! 